Article

\title{
Optimal Decision-Making of Renewable Energy Systems in Buildings in the Early Design Stage
}

\author{
Seung Hyo Baek ${ }^{1}$ and Byung Hee Lee ${ }^{2, *}$ \\ 1 Division of Building Science and Technology, College of Engineering, City University of Hong Kong, \\ Hong Kong, China; seunbaek@cityu.edu.hk \\ 2 Housing Environment Research and Innovation, Land \& Housing Institute, Sejong City 30065, Korea \\ * Correspondence: bhlee@lh.or.kr
}

Received: 11 February 2019; Accepted: 5 March 2019; Published: 10 March 2019

\begin{abstract}
Renewable energy systems (RES) in buildings should be designed carefully, not only because of the need for an optimal design, but also to comply with related laws. Therefore, the design of RES in the buildings requires close collaboration between architects and engineers from the beginning of the design process. To support such collaboration, this study proposes a simplified design method for RES in buildings during the early design stage. By using the proposed design method, design alternatives that meet the required energy standards as suggested by law are first generated. Further designs are made to evaluate the performance and cost of the design alternatives and to find the optimal types of RES for the building. The study also uses a case study to verify the applicability of the design method to the early design stage. Although the performance and cost of the different design alternatives are similar, the implementation of each type of RES in each design alternative is different. Nonetheless, by analyzing performance patterns and the cost ratio of each type of RES in each design alternative, the study allows the most suitable type of RES to be chosen for the building.
\end{abstract}

Keywords: renewable energy systems; decision-making; optimal design; early design stage

\section{Introduction}

To mitigate climate change problems, many countries and industries have made an effort to reduce greenhouse gas emissions [1,2]. There is growing concern that buildings are one of the most energy-intensive sectors and contributors to greenhouse gas emissions in developed countries [3,4]. According to recent reports by the U.S. Department of Energy (DOE), the building sector has a higher potential for reducing greenhouse gas emissions than other sectors [5]. There are many different ways to reduce greenhouse gas emissions from buildings. High-performance buildings have been regarded as one of the most advanced and effective ways of reducing greenhouse gas emissions [6-8]. The successful implementation of high-performance building requires the application of renewable energy systems (RES), as well as passive building design approaches $[9,10]$.

To combine these efforts, a number of countries including South Korea have established regulations to enforce the installation of RES in buildings [11-13]. The European Union (EU) has also set a target for all new buildings to be nearly zero-energy by 2020 [14]. Nearly zero-energy buildings have very high energy performance and the low amount of energy these buildings require come mostly from renewable energy sources. The U.S. Environmental Protection Agency (EPA) has also published the Energy and Environment Guide to Action to gather the latest best practices and opportunities, which the states are using to invest in energy efficiency, renewable energy, and combined heat and power [15]. According to regulations from the South Korean government, a portion of the building energy demand for newly-built public building with total floor area of at least $1000 \mathrm{~m}^{2}$ should be 
supplied from renewable energy sources. This portion is defined as the Mandatory Renewable Energy Supply Rates (MRESR).

Hence, the demand for RES is increasing, but there are a few difficulties in designing RES in buildings. First, the high cost of installing RES is still a barrier to applying RES in buildings [16]. Furthermore, RES are generally designed within a given budget, so simplified design techniques are required to consider both technical reliability and economic feasibility.

Second, increased collaboration between architects and engineers is needed from the beginning of the design process. The design process for RES in buildings generally begins after the architectural plans have been confirmed. During the design process, architectural plans including the building shape and floor plan are frequently modified by architects. These modifications change the required MRESR of the building. If the expected amounts of energy supplied by the RES do not meet the building's energy requirements, the RES design should also be modified. This process requires considerable time, effort, and cost.

Lastly, it is difficult to estimate the RES performance in a building in the early design stage. Different factors such as outdoor conditions, thermal properties of the ground, and building load patterns impact the performance of the RES. Several types of renewable resources, such as sunlight, solar heat, and geothermal energy, may be used in a building. As they include multiple types of resources and demands, as well as a number of related facilities from energy resources to demand sides, RES are very complex [2]. However, information about the RES and the building provided in the early design stage is not sufficient to estimate the performance of the RES. Therefore, a design method is needed to estimate the performance of the RES using available information in the early design stage. Moreover, the design method should consider effects of the main design parameters, which are determined in the early design stage.

A number of uncertain design parameters are related to the performance of the RES. These variables include major RES design parameters such as building shape and building area, which are generally determined in the early design stage. Therefore, an RES design method that is suitable for the early design stage is required. However, previous design tools have been based on detailed energy simulations with many input variables, which makes them unsuitable for decision-making in the early design stage. Hence, it is necessary to develop a simplified RES design method to apply during the early design stage.

This study proposes a simplified design method for RES in building during the early design stage. This design method assesses whether design alternatives meet the MRESR requirements. It also provides support to select suitable types of RES for the building by evaluating the performance and economic feasibility. First, previous RES design methods were reviewed and targets of the simplified RES design method were defined. A simplified design method consisting of four steps as follows was then proposed: establish the RES design objectives, generate design alternatives consisting of different RES, evaluate each design alternative, and determine the optimal RES design. Finally, a case study was assessed to verify the feasibility of the proposed simplified design method for the RES.

\section{Previous Design Methods and Tools for RES in Buildings}

\subsection{Design Methods for RES in Buildings}

The purpose of designing an RES for a building is generally to maximize energy generation from renewable resources or minimize the RES installation cost [17-24]. For this purpose, RES design methods were proposed to evaluate the performance of multiple renewable resources instead of considering only a single renewable energy source. This is because individual renewable energy sources are not normally enough to meet the required MRESR for the building. Thus, several studies have emphasized the importance of an optimal combination of RES [13,18,25,26]. Richardson and Harvey suggested that one load-balancing method is to determine the optimal lowest-cost mix of renewable energy sources, demand response, and energy storage to replace conventional fuels [18]. 
Vidal-Amaro et al. proposed a minimum total mix capacity (MTMC) method to determine the optimal mix of RES and fossil fuels in an electricity system by considering the hourly values of RES production and electricity demand [13]. Using the MTMC method, several combinations of biomass, wind, and solar power that achieved a minimum of $35 \%$ RES electricity production were identified.

A principle of RES design is to determine the appropriate type and size of each RES to meet the building's energy requirements. In addition, other building parameters included in the architectural plan should also be considered. Accordingly, many researchers have suggested that a combination of multiple renewable energy sources-such as geothermal, biomass, wind, solar, etc.-is necessary $[27,28]$. To design a RES considering the interrelation between architectural features and RES performance, close collaboration and communication between architects and engineers is needed. For example, installable capacities of the RES such as photovoltaic panels (PV), solar collectors, and ground heat exchangers depend on the area of the building envelope and site. Building orientation is another main factor affecting the performance of PV modules and solar collectors. Moreover, the heating and cooling loads of the building vary according to the building shape and orientation. Consequently, a suitable RES for the building can be modified.

Working together, architects and engineers should decide which type and size of RES is appropriate for the building and which architectural features should be changed to provide sufficient area to install the RES. This collaboration between architects and engineers should begin in the early design stage because decisions regarding the design of the RES at this point significantly influence the building performance $[29,30]$. Furthermore, determining the optimal RES for a building is a complex process due to the number of design variables, performance parameters, and constraints involved in the design process. Most of these variables and parameters are unknown in the early design stage. Therefore, in order to support collaboration between architects and engineers, a simplified method to design a RES for a building is necessary. With this method, optimal design alternatives can be generated that meet the MRESR under architectural conditions such as the building envelope, floor shape, site area, etc. In addition, a simplified design method for RES in buildings should support architects and engineers in evaluating the performance of each RES design alternative and make decisions regarding the optimal RES from the technical and economic perspectives.

\subsection{Design Tools for RES in Buildings}

To find the optimal RES design for a building, several design tools have commonly been used. These tools were developed to assess, analyze, and optimize the potential energy and cost impact of RES and energy-efficient technologies [31]. These tools differ in scale and complexity, as well as in the input required by the software to generate the intended output [31].

One widely used design tool is RETScreen. RETScreen was developed to evaluate energy production, life-cycle costs, and the reduction of greenhouse gas emissions of various types of renewable energy systems [32-36]. In RETScreen, the performance of different types of renewable energy sources, including wind power [37,38], hydro power [39,40], PV [41-43], combined heat and power (CHP) [35], bio energy [44,45], solar heating [33,46-48], and geothermal heating and cooling [49], can be evaluated. RETScreen allows users to compare the economic performance of conventional systems and RES alternative systems for optimal design. However, RETScreen is only appropriate for users with sufficient knowledge about RES. In addition, it is not easy for users to determine whether the design alternatives meet legislative requirements such as MRESR.

Another RES performance evaluation tool, MERIT, has the advantage that optimal systems are determined by analyzing whether energy supplies from renewable energy systems can meet the building load [50]. In MERIT, a matching analysis is performed to find the optimal RES that is most suitable for the building [51]. When the amount of energy supply at a given time is almost same as the energy demand at the same time, the matching analysis determines that it is well matched. Therefore, MERIT should be co-simulated with ESP-r, a dynamic building energy simulation program. To design stand-alone RES, MERIT is most appropriate for analyzing whether the design alternative is 
technically reliable or not. However, most RES in South Korea are connected to the grid, so evaluating the economic feasibility is as important as analyzing the system reliability.

Hybrid Optimization of Multiple Energy Resources (HOMER) is also widely used to evaluate RES performance. This tool provides support for optimizing micro-grid designs that include a combination of renewable energy sources, storage, and fossil-fuel energy generation [52]. The optimization algorithm greatly simplifies the design process for identifying least-cost options for micro-grids or other distributed generation electrical power systems. Therefore, HOMER is a complex software that has many different input options pertaining to system size, cost, lifetime, and depreciation [31]. Unlike the aforementioned evaluation programs, HOMER is used to evaluate types of renewable energy sources to generate electricity. Therefore, it is difficult to the evaluate feasibility of other RES such as geothermal energy and solar collectors.

In addition to commonly used RES design tools, other studies have also developed design tools and processes for implementing RES in buildings. Zhang et al. proposed a multi-criterion renewable energy system design optimization for net zero-energy buildings to consider uncertainties related to system performance [53]. Lu et al. investigated optimization methods for renewable energy systems in low-/zero-energy buildings by comparing the performance effectiveness of a single objective using a genetic algorithm and the effectiveness of multi-objectives using non-dominated sorting genetic algorithm optimization techniques [54]. In this study, a performance evaluation tool was developed using MATLAB. The tool was co-simulated with TRNSYS to consider the building heating and cooling load. Sharafi et al. developed a simulation-based meta-heuristic approach to determine the optimal size of a hybrid renewable energy system for residential buildings [55].

These previous studies made detailed performance simulations to determine optimal designs, but such methods are not easy to use in the early design stage. To overcome this problem, Kim \& Kim proposed an optimal sizing method for RES for school buildings based on simplified sizing equations [56]. While this study is suitable for school buildings, it is difficult to apply to other building types. Hence, RES design methods that estimate the energy production from renewable sources with variables available in the early design stage are necessary.

\section{Simplified Design Method for RES in Buildings in the Early Design Stage}

\subsection{Process of Simplified Design Method}

A simplified design method was proposed to meet four main goals of RES design in buildings during the early design stage: to meet the required MRESR for the building, to consider essential architectural design features determined in the early design stage, to determine optimal design alternatives, and to perform these processes quickly and simply. As shown in Figure 1, the simplified design method consists of four steps: establish objectives for RES design in the building, generate design alternatives, evaluate design alternatives, and determine optimal design alternatives.

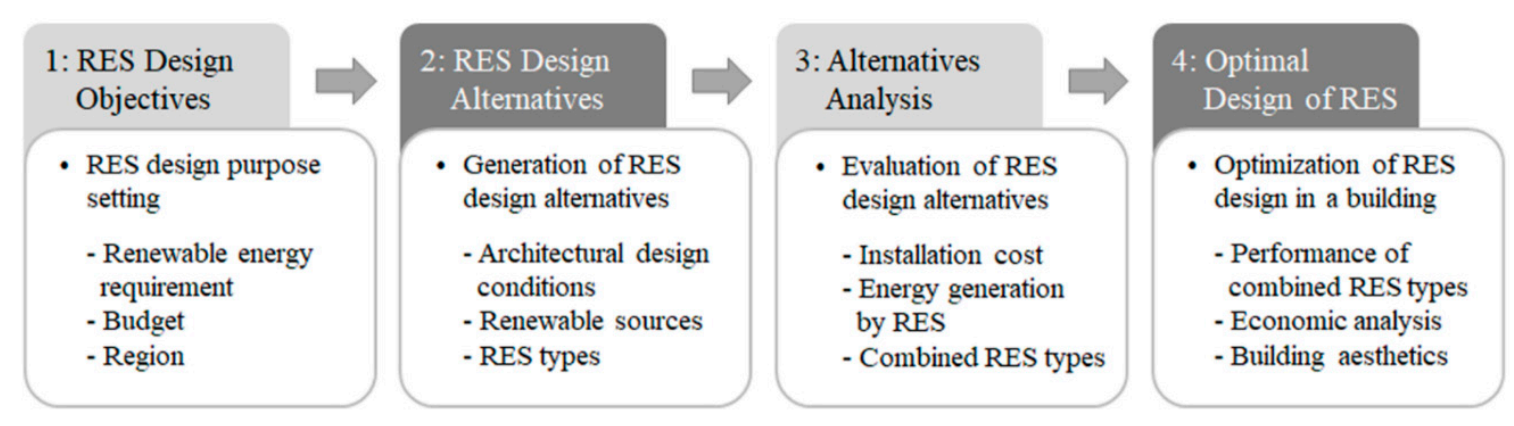

Figure 1. Process of the simplified design method.

In the first process, the amount of energy generation from renewable resources should be determined following the required MRESR for the building. To design a zero-energy building, 
for example, the proportion of energy from renewable resources compared to the total building energy consumption is $100 \%$. In most countries, this ratio is provided in building standards or legislation. The South Korean government has established legislation related to this ratio-i.e., MRESR - with the goal of strengthening it. The MRESR was 10\% in 2011, but will gradually increase to 30\% by 2020 .

The amount of energy from renewable resources is determined based on this ratio. In the study, the building energy consumption is calculated based on the energy consumption per unit area, as suggested by South Korean government. This data allows architects and engineers to quickly estimate the building energy consumption [57]. In addition, even if a number of design variables and parameters are unknown, this data enables the building energy consumption to be estimated in consideration of the building type and region. Table 1 shows the energy consumption per unit area according to building type and Table 2 shows the conversion coefficient by region. The conversion coefficient by region incorporates the regional difference in climate to the estimated data. For example, Jeju is located at the southernmost region in South Korea and has a humid subtropical climate, whereas Gongwon Yeongseo is located at the center of the Korean peninsula and has hot summers and a humid continental climate.

Table 1. Estimated data of building energy consumption by building type.

\begin{tabular}{|c|c|}
\hline Building Type & $\begin{array}{l}\text { Estimated Energy Consumption per Unit Area } \\
\qquad\left(\mathrm{kWh} /\left(\mathrm{m}^{2} \text { Year }\right)\right)\end{array}$ \\
\hline Military and prisons & 392.07 \\
\hline Broadcast facilities & 490.18 \\
\hline Office (public) & 371.66 \\
\hline Office (private) & 374.47 \\
\hline Cultural and assembly facilities & 412.03 \\
\hline Religious facilities & 257.49 \\
\hline Medical facilities & 643.52 \\
\hline Educational and R\&D facilities & 231.33 \\
\hline Social welfare facilities & 175.58 \\
\hline Youth facilities & 231.33 \\
\hline Sports facilities & 235.42 \\
\hline Cemeteries & 234.99 \\
\hline Tourism \& leisure facilities & 437.08 \\
\hline Funeral homes & 234.99 \\
\hline Retail & 408.45 \\
\hline Transport facilities & 374.47 \\
\hline Accommodation & 526.55 \\
\hline Entertainment facilities & 400.33 \\
\hline
\end{tabular}

Table 2. Conversion coefficient by South Korean region.

\begin{tabular}{cc}
\hline Region in South Korea & Conversion Coefficient \\
\hline Seoul & 1.00 \\
Incheon & 0.97 \\
Gyeonggi & 0.99 \\
Gangwon Yeongseo & 1.00 \\
Gangwon Yeongdong & 0.97 \\
Daejeon & 1.00 \\
North Chungcheong & 1.00 \\
North Jeolla & 1.04 \\
South Chuncheong and Sejong & 0.99 \\
Gwangju & 1.01 \\
Daegu & 1.04 \\
Busan & 0.93 \\
South Gyeongsang & 1.00 \\
Ulsan & 0.93 \\
North Gyeongsang & 0.98 \\
South Jeolla & 0.99 \\
Jeju & 0.97 \\
\hline
\end{tabular}


In the second step, RES design alternatives are generated to meet MRESR under the design conditions determined during the early design stage. Each design alternative consists of a combination of types of RES and their capacity. Design alternatives are generated by changing the capacity of each RES from minimum capacity (when a certain system is not installed in the building, the value is 0 ) to maximum capacity. The maximum capacity of each RES is determined by establishing how many units can be installed within the limited building envelope and site area. To find the maximum capacity, it is assumed that the installation of each system follows rules for maximizing their performance, such as the appropriate distance between each RES unit.

In the third step, every design alternative is evaluated to determine whether they meet the required MRESR of the building. For a quick estimation of energy from RES, in this study, the simple performance data are used. The simple performance data include the renewable energy generation per unit and the conversion coefficient of each RES. These are also provided in applicable laws from the South Korean government. Table 3 shows the amount of energy generation per RES unit and the RES conversion coefficient. For every building that is designed based on the corresponding law, the amount of energy generation from RES is estimated based on the values illustrated in Table 3. Consequently, these values have a significant impact on the selection of RES types; the RES type in which the energy generation per unit is significantly greater than the others can be selected straightaway to satisfy the MRESR requirement of the building. The conversion coefficient was suggested to support a balanced implementation of each RES type to buildings.

For all design alternatives, the amount of energy generation is calculated and compared with the amount of required energy from renewable resources. If none of the design alternatives meet the requirements, the architect and engineer should change the shape or height of the building and repeat the design process from the first step.

Table 3. Estimated energy-generation data per RES unit and its conversion coefficient.

\begin{tabular}{ccc}
\hline Type of RES & Energy Generation per RES Unit & Conversion Coefficient \\
\hline Fixed rooftop PV & $1358 \mathrm{kWh} / \mathrm{kWyear}$ & 1.56 \\
Rooftop solar tracker & $1765 \mathrm{kWh} / \mathrm{kWyear}$ & 1.68 \\
Building-integrated photovoltaics & $923 \mathrm{kWh} / \mathrm{kWyear}$ & 5.48 \\
Flat-plate solar collector & $596 \mathrm{kWh} / \mathrm{m}^{2}$ year & 1.42 \\
Single vacuum tube solar collector & $745 \mathrm{kWh} / \mathrm{m}^{2}$ year & 1.14 \\
Double vacuum tube solar collector & $745 \mathrm{kWh} / \mathrm{m}^{2}$ year & 1.14 \\
Closed-ground heat exchanger & $864 \mathrm{kWwh} / \mathrm{kWyear}$ & 1.09 \\
\hline
\end{tabular}

Finally, the optimal RES design alternative is determined. This includes several performance indexes such as cost, $\mathrm{CO} 2$ emissions, and the amount of energy generation from RES [58]. To consider the overall cost associated with the RES, the life cycle cost (LCC) is a more appropriate index than the installation cost; however, more importantly, the design alternative should meet the requirements of the related law. Therefore, this study primarily considered two indexes, the amount of energy generation and total installation cost, to obtain the optimal design alternatives.

When a number of design alternatives meet the RER requirements, the engineer can reduce the number of RES types by adjusting the installable area. The architect may not prefer rooftop PV or solar collectors because these systems may spoil the esthetics of the building. With the proposed design method, the engineer can regenerate and reevaluate design alternatives, ruling out those systems.

\subsection{A Design Tool to Support Simplified RES Design in Buildings}

The design tool was developed by implementing the proposed design method. It was developed using VBA, following input and output shown in Figure 2 and the algorithm shown in Figure 3. By entering essential input in the design tool, design alternatives that meet the required building MRESR are generated. The amount of energy produced in each design alternative and its cost are 
printed on the screen to assist the user in comparing design alternatives. The installation cost of each design is estimated based on the unit installation cost of each RES. Table 4 illustrates data regarding the unit installation cost provided by the applicable South Korean laws.

INPUT

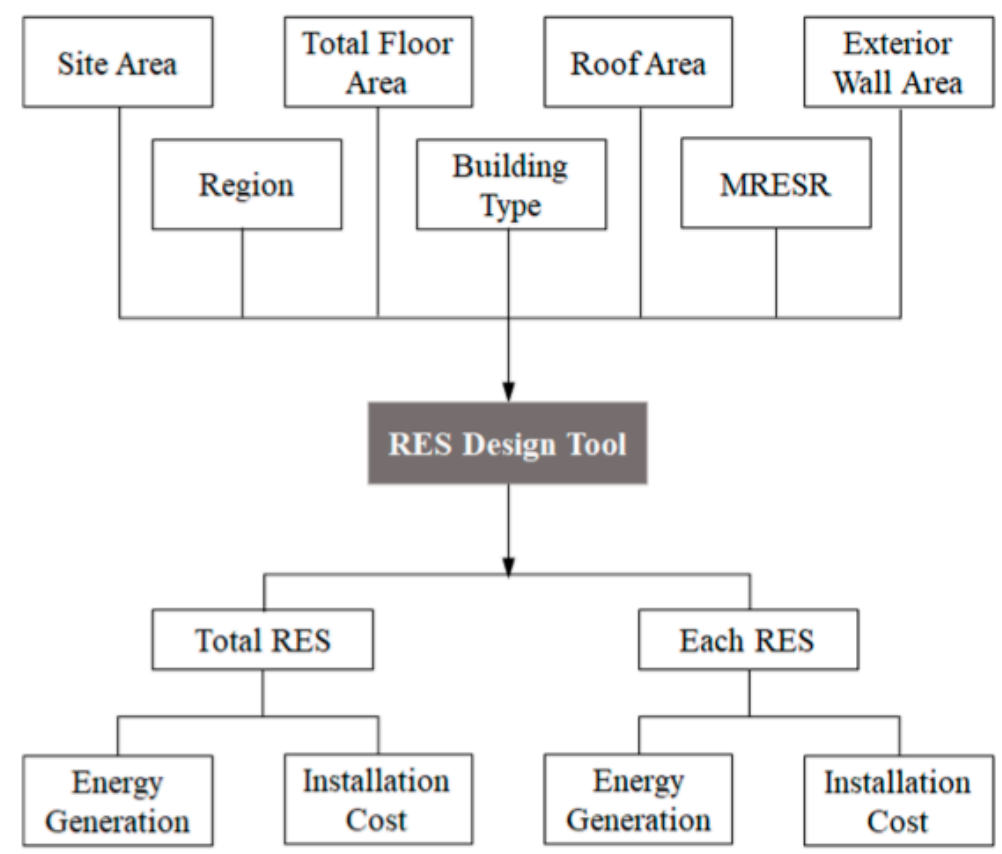

OUTPUT

Figure 2. Input and output of the design tool.

Table 4. Estimated data of installation cost for types of RES.

\begin{tabular}{cc}
\hline Type of RES & Installation Cost per RES Unit \\
\hline Fixed rooftop PV & $5578 \$ / \mathrm{kW}$ \\
Rooftop solar tracker & $6287 \$ / \mathrm{kW}$ \\
Building-integrated photovoltaics & $10,717 \$ / \mathrm{kW}$ \\
Flat-plate solar collector & $904 \$ / \mathrm{m}^{2}$ \\
Single vacuum tube solar collector & $1036 \$ / \mathrm{m}^{2}$ \\
Double vacuum tube solar collector & $904 \$ / \mathrm{m}^{2}$ \\
Closed-ground heat exchanger & $1125 \$ / \mathrm{kW}$ \\
\hline
\end{tabular}

This design tool relies on several assumptions. Among the variety of renewable energy sources-fixed rooftop PVs, rooftop solar trackers, building-integrated PVs (BIPV), flat-plate solar collectors, single vacuum tube solar collectors, double vacuum tube solar collectors, and closed-ground heat exchangers-which are commonly adopted in buildings in South Korea, were considered. It is assumed that fixed rooftop PVs, rooftop solar trackers, flat-plate solar collectors, and single and double vacuum tube solar collectors are installed on the roof and that BIPV systems are installed on the south-facing wall. It is also assumed that closed-ground heat exchanger is installed at the site area.

When designing the solar collectors and rooftop PVs, it is assumed that every unit faces south and is situated such that its shadow does not fall on adjacent units. The extractable heat rate from a closed-ground heat exchanger depends not only on the thermal properties of the ground and ground heat exchanger, but also on the distance between each ground heat exchanger. This study assumed 6 $\mathrm{m}$ as the optimal distance between each ground exchanger, but this value can be changed by the user. The maximum capacity is calculated based on the area of the roof, walls and site, the distance between each RES unit, and the capacity of each RES unit. These values are set by the user. 


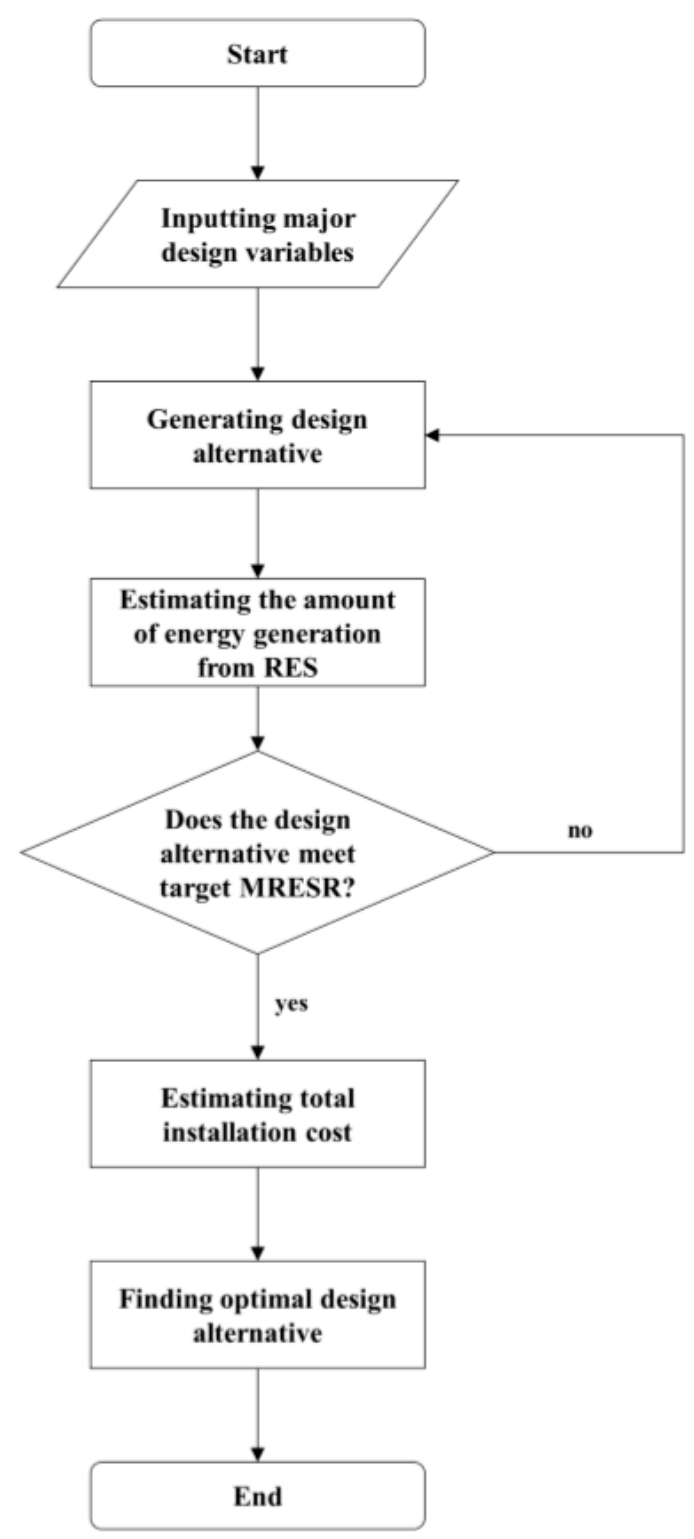

Figure 3. Flow chart of the design tool.

\section{Case Study}

A case study was used to demonstrate the applicability of the proposed design method. Since the method was proposed to support collaboration between architects and engineers during early design stage, the demonstration was made under the general architectural design conditions decided upon in the early design stage. In general, in the early design stage, the building shape, dimension, and building orientation are mainly determined by architects. In this method, the engineer calculates the amount of energy generated by RES based on the architect's initial design. The architect decides whether to keep or change the initial design based on the calculated energy output.

In this study, a building model is assumed as shown in Table 5. The building design conditions consist of five factors: total floor area, site area, roof area, exterior wall area, and MRESR. The total floor area and site area are necessary when deciding the building scale and number of floors. Particularly, the total floor area is an important design variable because it is used to estimate building energy consumption. The roof area and exterior wall area are also important for estimating the amount of energy coming from the rooftop PVs or solar collectors. The MRESR serves as a guideline for determining the amount of energy generated from RES or the initial cost of installing RES in a building. 
In this study, the building MRESR is assumed to be $50 \%$. This assumption reflects the mandatory energy capacity of renewable energy systems in the United States, Australia, and other countries by 2030, which is up to $50 \%$ of total energy consumption [59-62].

Table 5. Main design variables and parameters determined during the early design stage.

\begin{tabular}{cc}
\hline Design Variables and Parameters & Value (Unit) \\
\hline Region & Seoul, South Korea \\
Building type & Public office \\
Total floor area & $230\left(\mathrm{~m}^{2}\right)$ \\
Site area & $250\left(\mathrm{~m}^{2}\right)$ \\
Roof area (flat) & $30\left(\mathrm{~m}^{2}\right)$ \\
Exterior wall area (south-facing) & $30\left(\mathrm{~m}^{2}\right)$ \\
MRESR & $50(\%)$ \\
\hline
\end{tabular}

Figure 4 shows different building forms that can be generated with the architectural design conditions listed in Table 5. As shown in Figure 4A-2, the building consists of three stories and has a long rectangular shape, whereas Figure $4 \mathrm{~A}-1$ shows a building with five stories and a short rectangular shape. Comparing Figure 4A-1,A-2,B types of the building roof of Figure 4A-1,A-2 are flat and sloped roofs, whereas those of Figure $4 \mathrm{~B}$ are flat and gabled roofs. This means that even under the same architectural design conditions, the number of building stories and aspect ratio can be different. Using the simplified design, however, the engineer can estimate the energy generation from RES in the early design stage regardless of building shape. In addition, the architect can create a variety of building design alternatives without any RES limitations.

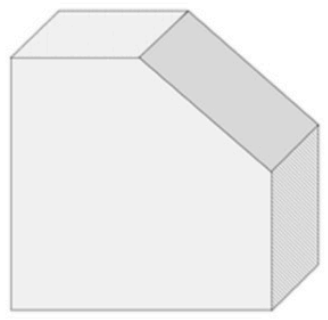

A-1) Design alternative 1

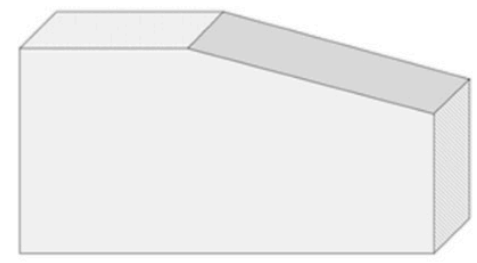

A-2) Design alternative 2

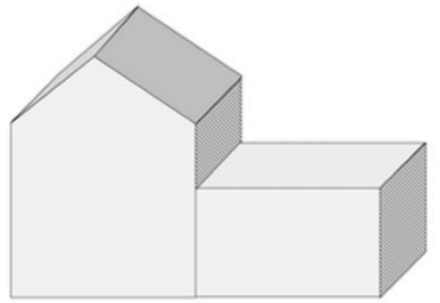

B) Design alternative 3

Figure 4. Different building forms with the same architectural design conditions.

\section{Results}

\subsection{Analysis of Design Alternatives with Similar Energy Generation}

If the energy consumption of the building was estimated to be approximately $85,481 \mathrm{kWh}$, the amount of energy that should be generated by RES is at least $42,740 \mathrm{kWh}$. By changing the combination of RES and number of RES units, design alternatives that meet the required MRESR were generated. A number of design alternatives meet the required MRESR, i.e., the amount of energy generation in those alternatives is greater than $42,740 \mathrm{kWh}$. Among all design alternatives, 30 with the least energy generation were selected for the analysis. Accordingly, the amount of energy production in those design alternatives is slightly larger than $42,740 \mathrm{kWh}$. In this case, fixed rooftop PVs, BIPVs, flat-plat solar collectors, single vacuum tube solar collectors, double vacuum tube solar collectors, and closed-ground heat exchangers were selected as the types of RES considered.

Table 6 shows the amount of energy generation and total installation cost of each design alternative. As shown, the amount of energy generation of the thirty design alternatives falls between $42,748 \mathrm{kWh}$ and $43,911 \mathrm{kWh}$. The difference between the minimum and maximum energy generation from RES is only $1163 \mathrm{kWh}$, which is less than $3 \%$ of the minimum amount of energy generated by RES. 
However, the installation cost of RES in the building has a different pattern from energy production. The installation cost of RES ranges from $\$ 69,317$ to $\$ 223,700$, and the maximum cost is more than three times the minimum cost. This implies a great difference in initial RES-installation cost, though there is little difference in energy generation via RES among the design alternatives.

To intuitively understand the performance of the 30 design alternatives selected, Figure 5 shows the energy generation ratio of each RES in each design alternative. As shown in Figure 5, the combination of RES varies among the different design alternatives. In the case A1-16, only three types of RES-fixed rooftop PVs, BIPVs, and closed-ground heat exchangers-were selected for the design alternatives. On the other hand, in cases A1-6, 9, 10, 11, 19, 25, 27, and 28, six types of RES-fixed rooftop PVs, BIPVs, flat-plate solar collectors, single vacuum tube solar collectors, double vacuum tube solar collectors, and closed-ground heat exchangers-were combined for the design alternatives.

Figure 6 shows the cost ratio of installing each RES in each design alternative. The average installation cost of the thirty design alternatives selected is $\$ 158,432$. The lowest cost of A1-23 is $\$ 69,371$ and the largest cost of A1-22 is $\$ 223,700$. For all design alternatives, BIPVs cost the most to install, followed by flat-plate solar collectors and closed-ground heat exchangers.

In addition, the installation cost also depends on the number of each RES units in each design alternative, even if the types of RES in the design alternatives are the same. For A1-12 and 30, BIPVs, flat-plate solar collectors, and closed-ground heat exchangers were selected. The amount of energy generation in A1-12 is $43,277 \mathrm{kWh}$ and the installation cost is $\$ 79,448$. The amount of energy generation in A1-30 is $43,911 \mathrm{kWh}$ and the installation cost is $\$ 171,844$. Although the amount of energy generation in both cases is almost the same, large differences in installation cost were found. This difference is due to the way in which the RES were combined in the design alternatives. In cases A1-12, the installation cost ratios of BIPVs, closed-ground heat exchangers, and flat-plate solar collectors are 81,8 , and $6 \%$, respectively. However, in case A1-30, the installation cost ratios of BIPVs, closed-ground heat exchangers and flat-plate solar collectors are 94,3 , and $3 \%$, respectively. In cases A1-12, the installation cost ratios of BIPVs, closed-ground heat exchangers, flat plate solar collectors, and others are $81,8,6$, and 5\%, respectively. However, in cases A1-30, the installation cost ratios of BIPVs, closed-ground heat exchangers, and others are 94,3 , and $3 \%$, respectively.

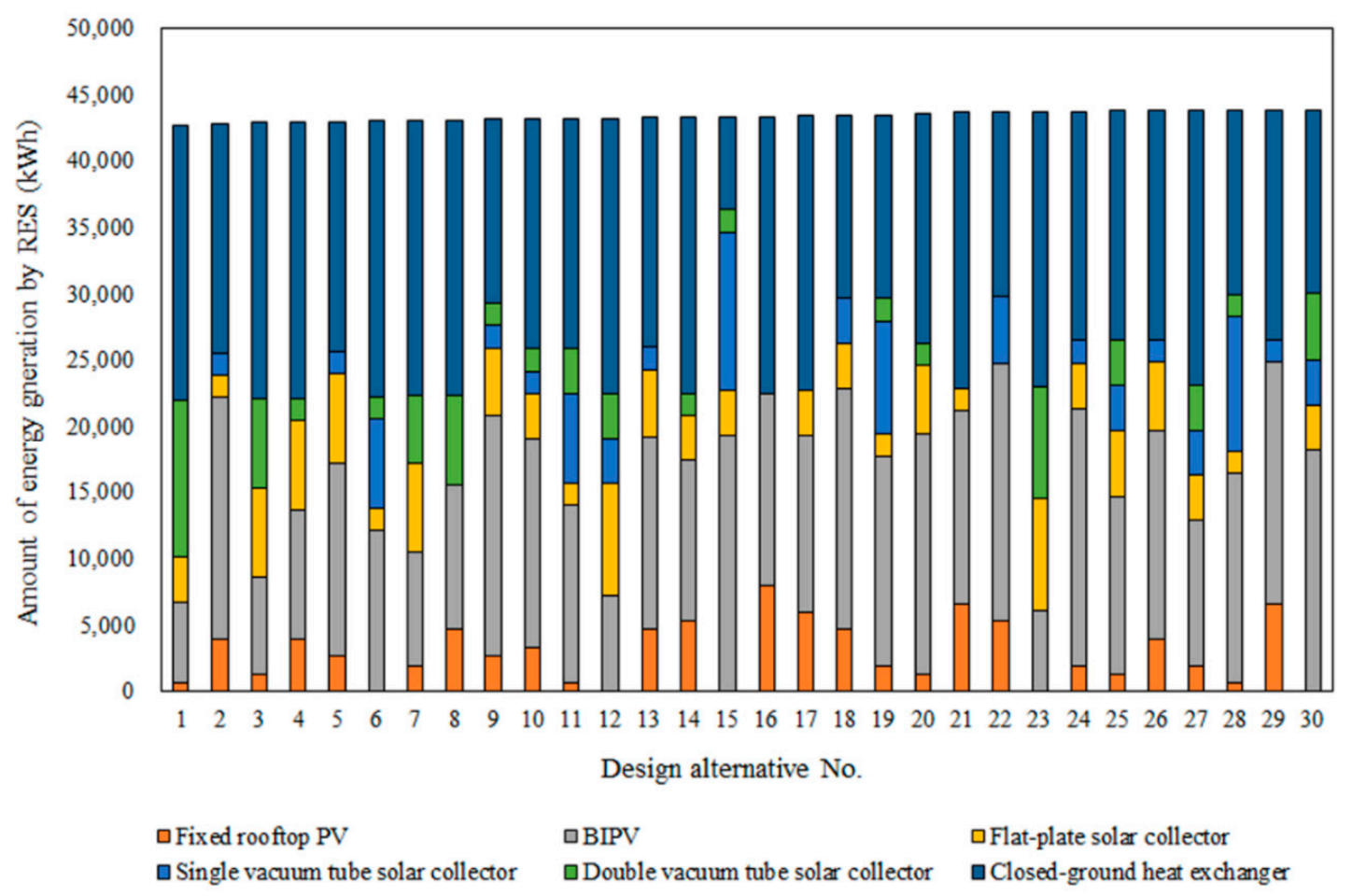

Figure 5. Amount of energy generation per RES in each design alternative. 
Table 6. RES design alternatives with least energy generation.

\begin{tabular}{|c|c|c|c|c|c|c|c|c|c|c|c|c|c|c|}
\hline \multirow{3}{*}{ No. } & \multirow{3}{*}{$\begin{array}{l}\text { Total Amount } \\
\text { of Energy } \\
\text { Generation } \\
(\mathbf{k W h})\end{array}$} & \multirow{3}{*}{$\begin{array}{c}\text { Total } \\
\text { Installation } \\
\text { Cost (\$) }\end{array}$} & \multicolumn{12}{|c|}{ RES Type } \\
\hline & & & \multicolumn{2}{|c|}{ Fixed Rooftop PV } & \multicolumn{2}{|c|}{ BIPV } & \multicolumn{2}{|c|}{$\begin{array}{c}\text { Flat-Plate Solar } \\
\text { Collector }\end{array}$} & \multicolumn{2}{|c|}{$\begin{array}{l}\text { Single Vacuum Tube } \\
\text { Solar Collector }\end{array}$} & \multicolumn{2}{|c|}{$\begin{array}{c}\text { Double Vacuum Tube } \\
\text { Solar Collector }\end{array}$} & \multicolumn{2}{|c|}{$\begin{array}{l}\text { Closed-Ground Heat } \\
\text { Exchanger }\end{array}$} \\
\hline & & & $\begin{array}{l}\text { Generation } \\
\text { (kWh) }\end{array}$ & Cost (\$) & $\begin{array}{l}\text { Generation } \\
(\mathrm{kWh})\end{array}$ & Cost (\$) & $\begin{array}{l}\text { Generation } \\
\text { (kWh) }\end{array}$ & Cost (\$) & $\begin{array}{l}\text { Generation } \\
\text { (kWh) }\end{array}$ & Cost (\$) & $\begin{array}{l}\text { Generation } \\
(\mathrm{kWh})\end{array}$ & Cost (\$) & $\begin{array}{l}\text { Generation } \\
\text { (kWh) }\end{array}$ & Cost (\$) \\
\hline A1-1 & 42,748 & 74,045 & 667 & 5578 & 6070 & 53,585 & 3385 & 1807 & 0 & 0 & 11,890 & 6325 & 20,736 & 6750 \\
\hline A1-2 & 42,884 & 201,785 & 4004 & 33,466 & 18,209 & 160,754 & 1693 & 904 & 1699 & 1036 & 0 & 0 & 17,280 & 5625 \\
\hline A1-3 & 42,919 & 89,436 & 1335 & 11,155 & 7284 & 64,302 & 6771 & 3614 & 0 & 0 & 6794 & 3614 & 20,736 & 6750 \\
\hline A1-4 & 42,921 & 130,470 & 4004 & 33,466 & 9711 & 85,736 & 6771 & 3614 & 0 & 0 & 1699 & 904 & 20,736 & 6750 \\
\hline A1-5 & 42,986 & 161,189 & 2669 & 22,311 & 14,567 & 128,604 & 6771 & 3614 & 1699 & 1036 & 0 & 0 & 17,280 & 5625 \\
\hline A1-6 & 43,061 & 119,870 & 0 & 0 & 12,139 & 107,170 & 1693 & 904 & 6794 & 4143 & 1699 & 904 & 20,736 & 6750 \\
\hline A1-7 & 43,102 & 104,827 & 2002 & 16,733 & 8498 & 75,019 & 6771 & 3614 & 0 & 0 & 5096 & 2711 & 20,736 & 6750 \\
\hline A1-8 & 43,127 & 145,861 & 4671 & 39,044 & 10,925 & 96,453 & 0 & 0 & 0 & 0 & 6794 & 3614 & 20,736 & 6750 \\
\hline A1-9 & 43,177 & 192,215 & 2669 & 22,311 & 18,209 & 160,754 & 5078 & 2711 & 1699 & 1036 & 1699 & 904 & 13,824 & 4500 \\
\hline A1-10 & 43,180 & 176,580 & 3337 & 27,888 & 15,781 & 139,321 & 3385 & 1807 & 1699 & 1036 & 1699 & 904 & 17,280 & 5625 \\
\hline A1-11 & 43,185 & 135,943 & 667 & 5578 & 13,353 & 117,887 & 1693 & 904 & 6794 & 4143 & 3397 & 1807 & 17,280 & 5625 \\
\hline A1-12 & 43,277 & 79,448 & 0 & 0 & 7284 & 64,302 & 8463 & 4518 & 3397 & 2071 & 3397 & 1807 & 20,736 & 6750 \\
\hline A1-13 & 43,295 & 177,019 & 4671 & 39,044 & 14,567 & 128,604 & 5078 & 2711 & 1699 & 1036 & 0 & 0 & 17,280 & 5625 \\
\hline A1-14 & 43,298 & 161,252 & 5339 & 44,621 & 12,139 & 107,170 & 3385 & 1807 & 0 & 0 & 1699 & 904 & 20,736 & 6750 \\
\hline A1-15 & 43,309 & 183,682 & 0 & 0 & 19,423 & 171,471 & 3385 & 1807 & 11,890 & 7250 & 1699 & 904 & 6912 & 2250 \\
\hline A1-16 & 43,311 & 202,286 & 8008 & 66,932 & 14,567 & 128,604 & 0 & 0 & 0 & 0 & 0 & 0 & 20,736 & 6750 \\
\hline A1-17 & 43,480 & 176,643 & 6006 & 50,199 & 13,353 & 117,887 & 3385 & 1807 & 0 & 0 & 0 & 0 & 20,736 & 6750 \\
\hline A1-18 & 43,487 & 208,177 & 4671 & 39,044 & 18,209 & 160,754 & 3385 & 1807 & 3397 & 2071 & 0 & 0 & 13,824 & 4500 \\
\hline A1-19 & 43,491 & 167,539 & 2002 & 16,733 & 15,781 & 139,321 & 1693 & 904 & 8493 & 5179 & 1699 & 904 & 13,824 & 4500 \\
\hline A1-20 & 43,600 & 181,149 & 1335 & 11,155 & 18,209 & 160,754 & 5078 & 2711 & 0 & 0 & 1699 & 904 & 17,280 & 5625 \\
\hline A1-21 & 43,669 & 192,034 & 6673 & 55,777 & 14,567 & 128,604 & 1693 & 904 & 0 & 0 & 0 & 0 & 20,736 & 6750 \\
\hline A1-22 & 43,681 & 223,700 & 5339 & 44,621 & 19,423 & 171,471 & 0 & 0 & 5096 & 3107 & 0 & 0 & 13,824 & 4500 \\
\hline A1-23 & 43,762 & 69,371 & 0 & 0 & 6070 & 53,585 & 8463 & 4518 & 0 & 0 & 8493 & 4518 & 20,736 & 6750 \\
\hline A1-24 & 43,789 & 196,672 & 2002 & 16,733 & 19,423 & 171,471 & 3385 & 1807 & 1699 & 1036 & 0 & 0 & 17,280 & 5625 \\
\hline A1-25 & 43,840 & 141,256 & 1335 & 11,155 & 13,353 & 117,887 & 5078 & 2711 & 3397 & 2071 & 3397 & 1807 & 17,280 & 5625 \\
\hline A1-26 & 43,842 & 182,158 & 4004 & 33,466 & 15,781 & 139,321 & 5078 & 2711 & 1699 & 1036 & 0 & 0 & 17,280 & 5625 \\
\hline A1-27 & 43,843 & 125,621 & 2002 & 16,733 & 10,925 & 96,453 & 3385 & 1807 & 3397 & 2071 & 3397 & 1807 & 20,736 & 6750 \\
\hline A1-28 & 43,855 & 157,420 & 667 & 5578 & 15,781 & 139,321 & 1693 & 904 & 10,192 & 6214 & 1699 & 904 & 13,824 & 4500 \\
\hline A1-29 & 43,861 & 223,192 & 6673 & 55,777 & 18,209 & 160,754 & 0 & 0 & 1699 & 1036 & 0 & 0 & 17,280 & 5625 \\
\hline A1-30 & 43,911 & 171,844 & 0 & 0 & 18,209 & 160,754 & 3385 & 1807 & 3397 & 2071 & 5096 & 2711 & 13,824 & 4500 \\
\hline
\end{tabular}




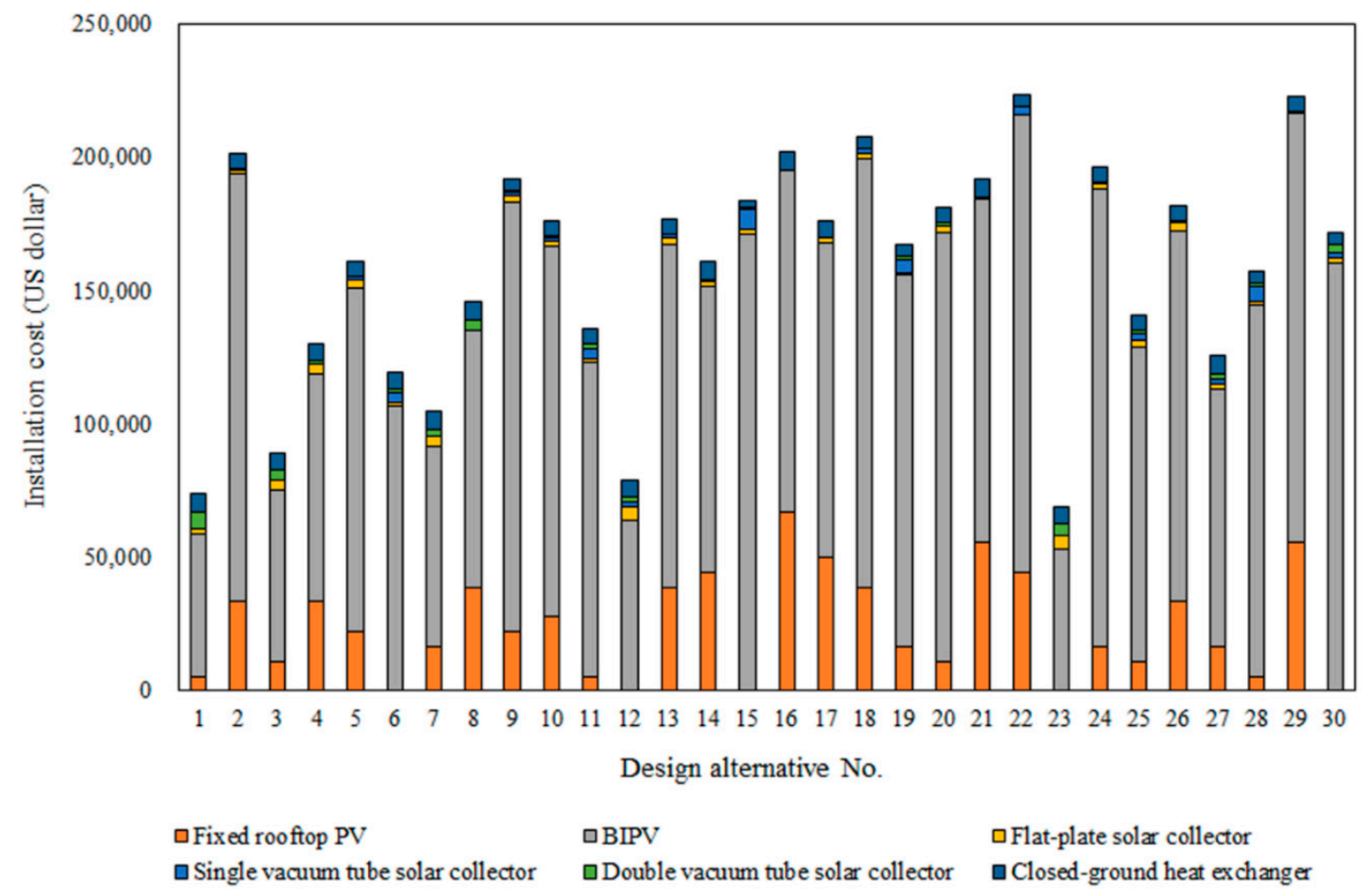

Figure 6. Installation cost of each RES in each design alternative.

\subsection{Analysis of Design Alternatives with Similar Energy Generation and Installation Cost}

In the previous section, the amount of energy generation and installation cost of design alternatives with the least energy generation were analyzed. The study found large differences in installation cost among the design alternatives. This section presents an analysis of the amount of energy generation and installation cost of each design alternative by narrowing down the design alternatives. For this purpose, by limiting both the installation cost and MRESR, design alternatives were selected anew. In reference to the minimum installation cost obtained in the previous section, the maximum installation cost per RES was calculated to be $\$ 72,840$ by adding $5 \%$ to its minimum cost. The maximum installation cost is defined as the acceptable installation cost. Consequently, new design alternatives were chosen for which the cost was higher than the minimum installation cost and smaller than the acceptable installation cost. Nevertheless, the amount of energy generation in these design alternatives is slightly larger than $42,740 \mathrm{kWh}$. There is no limitation to combining types of RES and maximizing the energy generation from RES in a building.

Table 7 illustrates the amount of energy generation and cost of the 30 design alternatives selected. As shown in the Table, the costs range from $\$ 69,371$ to $\$ 69,635$. The difference between minimum and maximum cost is $\$ 264$, which is only $0.4 \%$ of the minimum RES installation cost. The amount of energy generated from RES for each design alternative ranges between 40,732 kWh and 43,792 kWh. The difference between minimum and maximum energy production per RES is $60 \mathrm{kWh}$, which is $0.14 \%$ of the amount of minimum energy generation from RES.

Figure 7 shows a graph of the energy generation ratio of each RES in each design alternative. The study found that the amount of energy generation from BIPVs was the same, with $6070 \mathrm{kWh}$ for all design alternatives, and that of closed-ground heat exchangers was also the same, with 20,736 kWh. For all design alternatives, the total amount of energy generation from BIPVs and closed-ground heat exchangers met more than half the required amounts of energy generation. These results indicate that BIPVs and closed-ground heat exchangers should be considered as priorities. 
Table 7. RES design alternatives in terms of similar installation cost.

\begin{tabular}{|c|c|c|c|c|c|c|c|c|c|c|c|c|c|c|}
\hline \multirow{3}{*}{ No. } & \multirow{3}{*}{$\begin{array}{c}\text { Total } \\
\text { Amount of } \\
\text { Energy } \\
\text { Generation } \\
(\mathrm{kWh})\end{array}$} & \multirow{3}{*}{$\begin{array}{c}\text { Total } \\
\text { Installation } \\
\text { Cost }(\$)\end{array}$} & \multicolumn{12}{|c|}{ RES Type } \\
\hline & & & \multicolumn{2}{|c|}{ Fixed Rooftop PV } & \multicolumn{2}{|c|}{ BIPV } & \multicolumn{2}{|c|}{$\begin{array}{l}\text { Flat-Plate Solar } \\
\text { Collector }\end{array}$} & \multicolumn{2}{|c|}{$\begin{array}{l}\text { Single Vacuum Tube } \\
\text { Solar Collector }\end{array}$} & \multicolumn{2}{|c|}{$\begin{array}{c}\text { Double Vacuum Tube } \\
\text { Solar Collector }\end{array}$} & \multicolumn{2}{|c|}{$\begin{array}{l}\text { Closed-Ground Heat } \\
\text { Exchanger }\end{array}$} \\
\hline & & & $\begin{array}{l}\text { Generation } \\
\text { (kWh) }\end{array}$ & Cost (\$) & $\begin{array}{l}\text { Generation } \\
\text { (kWh) }\end{array}$ & Cost (\$) & $\begin{array}{l}\text { Generation } \\
\text { (kWh) }\end{array}$ & Cost (\$) & $\begin{array}{l}\text { Generation } \\
\text { (kWh) }\end{array}$ & Cost (\$) & $\begin{array}{l}\text { Generation } \\
\text { (kWh) }\end{array}$ & Cost (\$) & $\begin{array}{l}\text { Generation } \\
(\mathbf{k W h})\end{array}$ & Cost (\$) \\
\hline A2-1 & 43,792 & 69,371 & 0 & 0 & 6070 & 53,585 & 0 & 0 & 0 & 0 & 16,986 & 9036 & 20,736 & 6750 \\
\hline A2-2 & 43,786 & 69,371 & 0 & 0 & 6070 & 53,585 & 1693 & 904 & 0 & 0 & 15,287 & 8132 & 20,736 & 6750 \\
\hline $\mathrm{A} 2-3$ & 43,780 & 69,371 & 0 & 0 & 6070 & 53,585 & 3385 & 1807 & 0 & 0 & 13,589 & 7229 & 20,736 & 6750 \\
\hline A2-4 & 43,774 & 69,371 & 0 & 0 & 6070 & 53,585 & 5078 & 2711 & 0 & 0 & 11,890 & 6325 & 20,736 & 6750 \\
\hline A2-5 & 43,768 & 69,371 & 0 & 0 & 6070 & 53,585 & 6771 & 3614 & 0 & 0 & 10,192 & 5421 & 20,736 & 6750 \\
\hline A2-6 & 43,762 & 69,371 & 0 & 0 & 6070 & 53,585 & 8463 & 4518 & 0 & 0 & 8493 & 4518 & 20,736 & 6750 \\
\hline A2-7 & 43,756 & 69,371 & 0 & 0 & 6070 & 53,585 & 10,156 & 5421 & 0 & 0 & 6794 & 3614 & 20,736 & 6750 \\
\hline A2-8 & 43,750 & 69,371 & 0 & 0 & 6070 & 53,585 & 11,848 & 6325 & 0 & 0 & 5096 & 2711 & 20,736 & 6750 \\
\hline A2-9 & 43,744 & 69,371 & 0 & 0 & 6070 & 53,585 & 13,541 & 7229 & 0 & 0 & 3397 & 1807 & 20,736 & 6750 \\
\hline A2-10 & 43,738 & 69,371 & 0 & 0 & 6070 & 53,585 & 15,234 & 8132 & 0 & 0 & 1699 & 904 & 20,736 & 6750 \\
\hline A2-11 & 43,732 & 69,371 & 0 & 0 & 6070 & 53,585 & 16,926 & 9036 & 0 & 0 & 0 & 0 & 20,736 & 6750 \\
\hline A2-12 & 43,792 & 69,503 & 0 & 0 & 6070 & 53,585 & 0 & 0 & 1699 & 1036 & 15,287 & 8132 & 20,736 & 6750 \\
\hline A2-13 & 43,786 & 69,503 & 0 & 0 & 6070 & 53,585 & 1693 & 904 & 1699 & 1036 & 13,589 & 7229 & 20,736 & 6750 \\
\hline A2-14 & 43,780 & 69,503 & 0 & 0 & 6070 & 53,585 & 3385 & 1807 & 1699 & 1036 & 11,890 & 6325 & 20,736 & 6750 \\
\hline A2-15 & 43,774 & 69,503 & 0 & 0 & 6070 & 53,585 & 5078 & 2711 & 1699 & 1036 & 10,192 & 5421 & 20,736 & 6750 \\
\hline A2-16 & 43,768 & 69,503 & 0 & 0 & 6070 & 53,585 & 6771 & 3614 & 1699 & 1036 & 8493 & 4518 & 20,736 & 6750 \\
\hline A2-17 & 43,762 & 69,503 & 0 & 0 & 6070 & 53,585 & 8463 & 4518 & 1699 & 1036 & 6794 & 3614 & 20,736 & 6750 \\
\hline A2-18 & 43,756 & 69,503 & 0 & 0 & 6070 & 53,585 & 10,156 & 5421 & 1699 & 1036 & 5096 & 2711 & 20,736 & 6750 \\
\hline A2-19 & 43,750 & 69,503 & 0 & 0 & 6070 & 53,585 & 11,848 & 6325 & 1699 & 1036 & 3397 & 1807 & 20,736 & 6750 \\
\hline A2-20 & 43,744 & 69,503 & 0 & 0 & 6070 & 53,585 & 13,541 & 7229 & 1699 & 1036 & 1699 & 904 & 20,736 & 6750 \\
\hline A2-21 & 43,738 & 69,503 & 0 & 0 & 6070 & 53,585 & 15,234 & 8132 & 1699 & 1036 & 0 & 0 & 20,736 & 6750 \\
\hline A2-22 & 43,792 & 69,635 & 0 & 0 & 6070 & 53,585 & 0 & 0 & 3397 & 2071 & 13,589 & 7229 & 20,736 & 6750 \\
\hline A2-23 & 43,786 & 69,635 & 0 & 0 & 6070 & 53,585 & 1693 & 904 & 3397 & 2071 & 11,890 & 6325 & 20,736 & 6750 \\
\hline A2-24 & 43,780 & 69,635 & 0 & 0 & 6070 & 53,585 & 3385 & 1807 & 3397 & 2071 & 10,192 & 5421 & 20,736 & 6750 \\
\hline A2-25 & 43,774 & 69,635 & 0 & 0 & 6070 & 53,585 & 5078 & 2711 & 3397 & 2071 & 8493 & 4518 & 20,736 & 6750 \\
\hline A2-26 & 43,768 & 69,635 & 0 & 0 & 6070 & 53,585 & 6771 & 3614 & 3397 & 2071 & 6794 & 3614 & 20,736 & 6750 \\
\hline A2-27 & 43,762 & 69,635 & 0 & 0 & 6070 & 53,585 & 8463 & 4518 & 3397 & 2071 & 5096 & 2711 & 20,736 & 6750 \\
\hline A2-28 & 43,756 & 69,635 & 0 & 0 & 6070 & 53,585 & 10,156 & 5421 & 3397 & 2071 & 3397 & 1807 & 20,736 & 6750 \\
\hline A2-29 & 43,750 & 69,635 & 0 & 0 & 6070 & 53,585 & 11,848 & 6325 & 3397 & 2071 & 1699 & 904 & 20,736 & 6750 \\
\hline A2-30 & 43,744 & 69,635 & 0 & 0 & 6070 & 53,585 & 13,541 & 7229 & 3397 & 2071 & 0 & 0 & 20,736 & 6750 \\
\hline
\end{tabular}




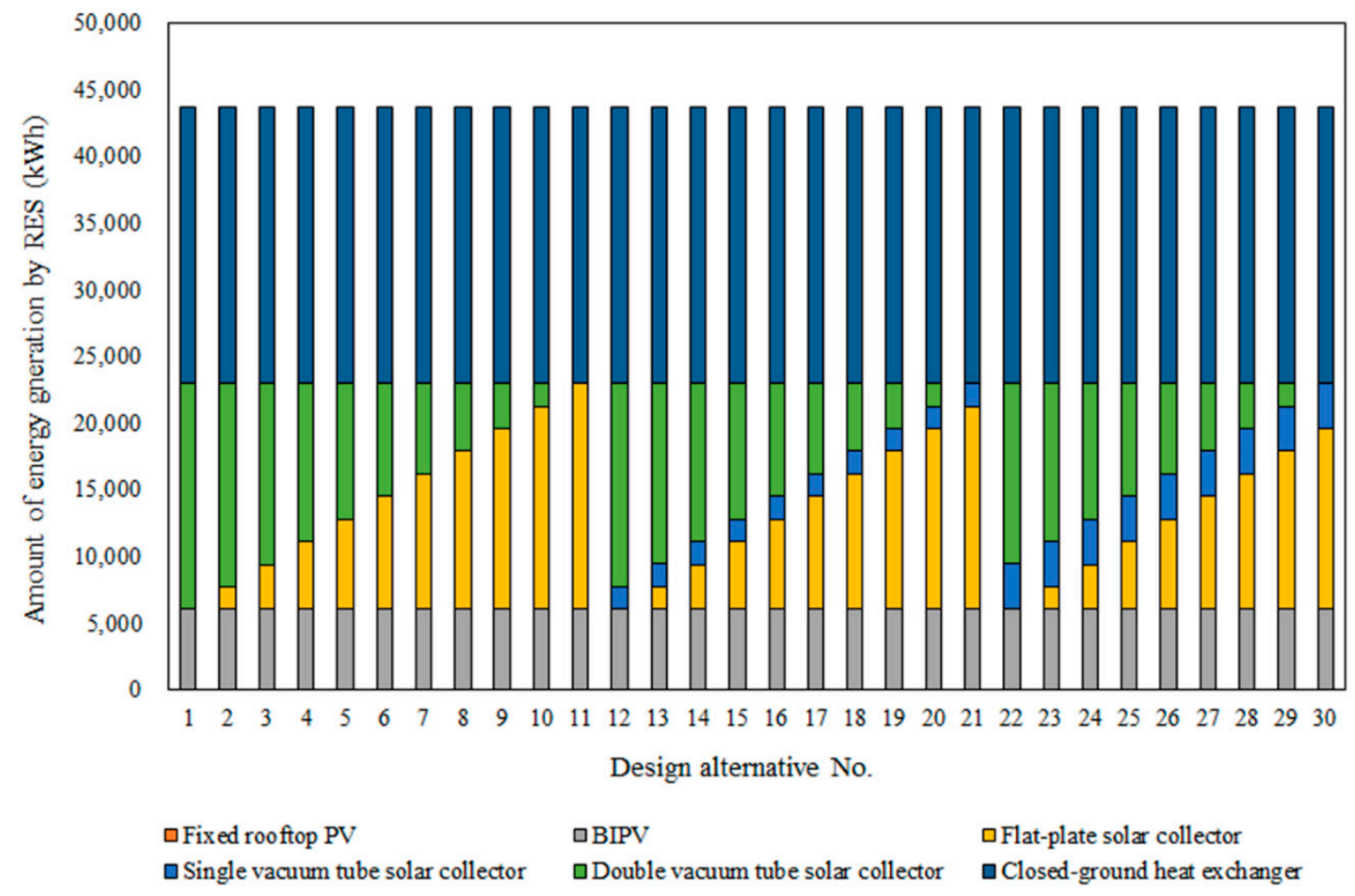

Figure 7. Amount of energy generation per RES in each design alternative.

Nonetheless, other RES were also selected for design alternatives, which means that BIPVs and closed-ground heat exchangers alone are not sufficient to meet the required MRESR due to the limitation of the building walls and site areas. To meet the remaining required amounts of energy generation, flat-plate solar collectors, single vacuum tube solar collectors, and double vacuum tube solar collectors were combined. The number of units of each RES differs according to the design alternative. In cases of A2-11, only flat-plate solar collectors were chosen to produce the remaining required amounts of energy generation. As well, in cases A2-28, only double vacuum tube solar collectors were selected. However, for most design alternatives, multiple RES types were selected.

\section{Discussion on Decision-Making for Optimal RES Design}

These results show that the amount of energy generation and installation cost differ by design alternative even when the design alternatives were narrowed down by MRESR and acceptable cost. A difference in amount of energy generation was also found, which may be caused by the way in which the RESs were combined. In spite of these characteristics, important insights can be gained from the results. By examining the selected design alternatives in Section 5.1, the study found that the amount of energy generation from closed-ground heat exchangers and BIPVs met more than half the required amounts of energy generation. The amount of energy generation from BIPVs and closed ground heat-exchangers differs in each design alternative. Nonetheless, most energy is generated by BIPVs and closed ground-heat exchangers in all design cases. This means that installing BIPVs and closed ground heat-exchangers is essential for meeting the required MRESR.

In the results of Section 5.1, the cost of design alternatives differs significantly compared to the difference in amount of energy generation. By following two criteria-i.e., MRESR and acceptable cost-30 design alternatives were selected from among all design alternatives. Like the patterns seen in Section 5.1, the data in Figure 8 shows that the amount of energy generation from BIPVs and closed-ground heat exchangers accounts for more than half the required energy generation. From these results, engineers and architects can rely on BIPVs and closed ground-heat exchangers as primary RES in meeting the required MRESR. 
The study also found different patterns in the results of Sections 5.1 and 5.2. When only MRESR is considered as the design objective, there is considerable difference in energy generation from BIPVs and closed-ground heat exchangers depending on the design alternative. On the contrary, when both MRESR and acceptable cost were considered, there is little difference in energy generation from BIPVs and closed-ground heat exchangers according to the design alternative. The study found meaningful results by considering only one criterion, but clearer findings were obtained when two criteria were considered.

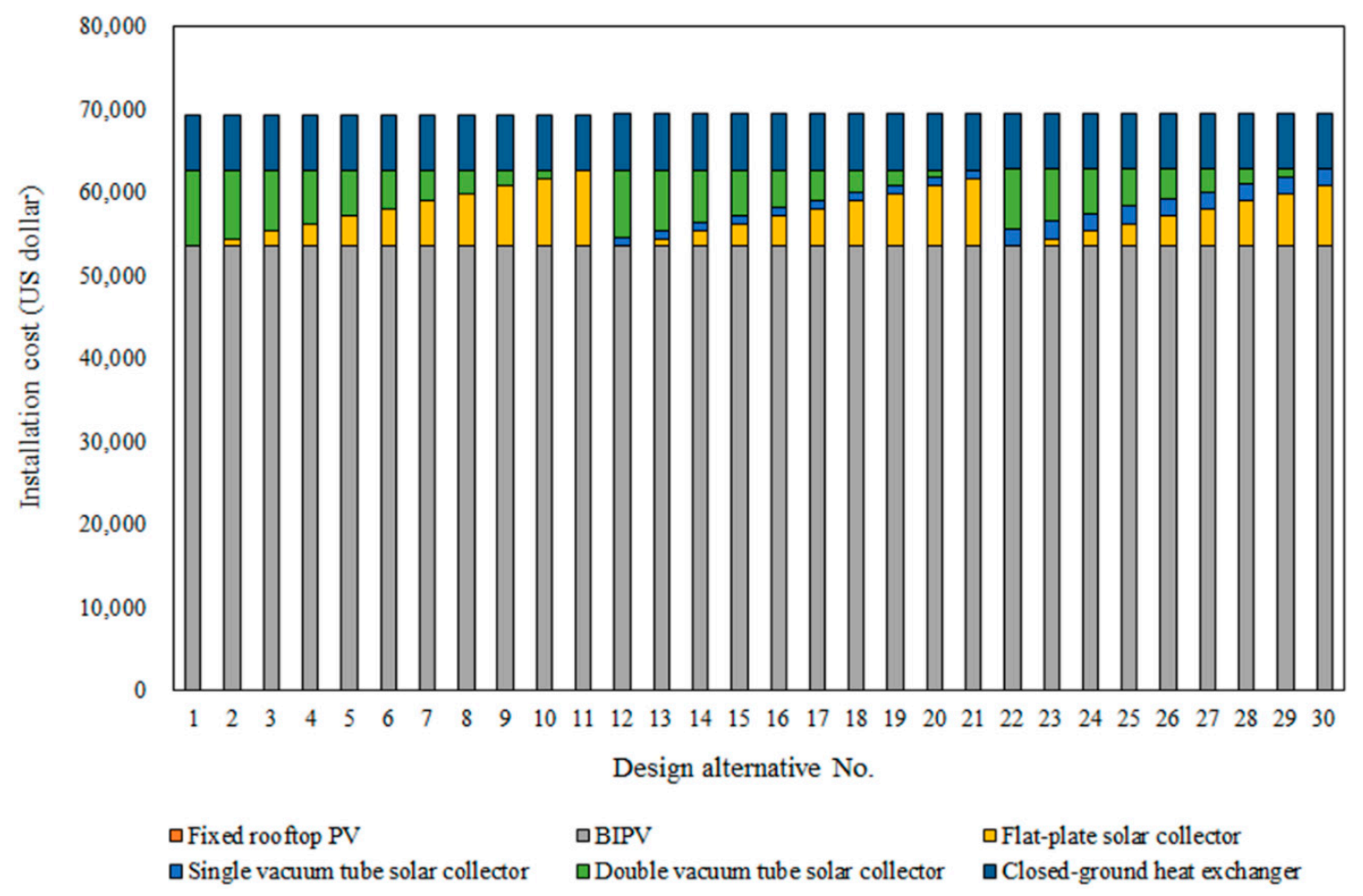

Figure 8. Installation cost of each RES in each design alternative.

By examining the results illustrated in Figure 8, the study also provided another insight for architects and engineers for optimal RES design. The amount of energy generation from closed-ground heat exchangers is almost half the required energy generation, while the installation cost of closed-ground heat exchangers is about a tenth of the total installation cost of its corresponding design alternative. For BIPVs, the energy generation ratio and installation cost are $14 \%$ and $77 \%$, respectively. From these results, we can conclude that closed-ground heat exchangers are more favorable in terms of both of energy generation and cost in this design case.

Nonetheless, BIPVs and closed-ground heat exchangers alone are not sufficient to meet the required MRESR, and additional RES are therefore required. In this design case, flat-plate solar collectors, single vacuum tube solar collectors, and double vacuum tube solar collectors were selected. From the results in Figures 7 and 8, no significant advantage of any particular RES was found. Flat-plate solar collectors are generally cheaper than vacuum tube solar collectors, but they have weaker performance. In addition, the components of each solar collector system are different, which means that differences exist in terms of maintenance, installation, and operational costs. With the parameters adopted in the proposed design method, these differences in cost and performance between each type of solar collector do not seem to be considered sufficiently. To determine more suitable solar collector types for a building, improving the proposed design method is essential. In this study, estimating the performance of each RES is solely based on the performance coefficients as listed in Table 3. The performance coefficients were established by the South Korean government for the purpose not only of simplifying estimation but also ensuring that the estimation processes of engineers 
and/or architects are identical. If engineers and/or architects use different design tools or make different assumptions about estimations of performance, the expected performance or costs of design variables can be different, even when the same RES are analyzed. Because the proposed method adopted these performance coefficients, it limits the estimation of performance of each solar collector. Accordingly, to evaluate the performance of each solar collector, improving the performance coefficients so that they consider the effects of outdoor conditions, building loads, and system configurations is necessary.

In the case study considered in this paper, the target MRESR was set as 50\%. This implies that the energy generated from RES of a building should be greater than half the total energy consumption. If the building envelope and site areas are large, the implementation of one RES type may sufficiently supply the required energy. However, in general, the building envelope and site areas are limited; therefore, it is difficult to design a single RES type to satisfy the MRESR requirement. Conversely, if the MRESR is low, a single RES type might suffice. For example, if the MRESR is set as $10 \%$ in the case study, the required quantity of the energy generated from the RES is adjusted to $8757 \mathrm{kWh}$. According to the results in Table 7, the energy generated by a closed-ground heat exchanger is $20,736 \mathrm{kWh}$, which implies that it can satisfy the MRESR requirement. However, as the MRESR increases, a single RES type will no longer be sufficient to satisfy the requirement. In conclusion, for public building designs, which should follow the corresponding law, multiple RES types are required to satisfy the MRESR requirement.

As mentioned in the Introduction, since a number of design variables and performance parameters are not decided during the early design stage, the accurate estimation of the RES performance in the building is difficult. Under such uncertain design conditions, a performance evaluation that completely considers the characteristics of building loads, system configuration, and outdoor conditions seems irrelevant. Therefore, this study sought to propose a simplified design method with the design variables available during the early design stage. However, if more appropriate and detailed design parameters or methods are provided in the next design step, they may be used by the architects and engineers to design the most appropriate RES.

\section{Conclusions}

The objective of this study was to suggest a simplified design method for RES in buildings during the early design stage. The proposed design method consisted of four steps and the design tool was developed based on the method. The study demonstrated that the simplified RES design method can be used to estimate the amount of energy generation and cost from each RES through a few design variables in the early design stage. The results of the study show that the total amount of energy generation differs depending on the combination of RES, even when the initial cost to apply the RES in a building is similar. It also shows that according to the way in which the types of RES are combined, various design alternatives with similar energy-generation and cost performance can be created.

By examining the amount of energy generation and installation cost ratio of each RES in each feasible design alternative, the study showed that BIPVs and closed-ground heat exchangers are essential for meeting the MRESR for the case study. Furthermore, closed-ground heat exchangers are more favorable than BIPVs because they provide more energy with same installation cost. With these findings, the proposed design method will enable architects and engineers to decide which types of RES are essential and most favorable in the early design stage.

As mentioned several times, only a few essential design variables are available in the early design stage. Architects and engineers need to keep in mind that they should choose the optimal RES in the building with the available information. However, the study obtained a number of feasible design alternatives that meet the MRESR and cost less. With these results, detailed decisions such as the optimal number of RES units and system configuration are not feasible during early design stage. However, with the proposed design method, we found that it is possible to choose the most appropriate types of RES for the building. 
Author Contributions: Conceptualization, S.H.B.; Methodology, S.H.B.; Software, S.H.B.; Formal analysis, B.H.L.; Investigation, S.H.B. and B.H.L.; Data curation, B.H.L.; Writing-original draft preparation, S.H.B.; Writing—review and editing, B.H.L.; Visualization, B.H.L.; Supervision, B.H.L.

Funding: This research received no external funding.

Conflicts of Interest: The authors declare no conflict of interest.

\section{References}

1. Han, S.K.; Kim, J.Y. An Optimization Model to Design and Analysis of Renewable Energy Supply Strategies for Residential Sector. Renew. Energy 2017, 112, 222-234. [CrossRef]

2. Liu, H.; Andersen, G.B.; Greiner, M. Cost-optimal Design of a Simplified Highly Renewable Chinese Electricity Network. Energy 2018, 147, 534-546. [CrossRef]

3. IPCC. Climate Change 2014: Mitigation of Climate Change, Contribution of Working Group III to the Fifth Assessment Report of the Intergovernmental Panel on Climate Change; Cambridge University Press: Cambridge, UK; New York, NY, USA, 2014; pp. 6-8.

4. Schmidyt, M.; Crawford, R.H. A Framework for the Integrated Optimization of the Life Cycle Greenhouse Gas Emissions and Cost of Buildings. Energy Build. 2018, 171, 155-167. [CrossRef]

5. EPA. Inventory of U.S. Greenhouse Gas Emissions and Sinks 1990-2016; EPA: Washington, DC, USA, 2018; pp. 2-1-2-19.

6. Dahlhausen, M.; Heidarinejad, M.; Srebric, J. Building Energy Retrofits under Capital Constraints and Greenhouse Gas Pricing Scenarios. Energy Build. 2015, 107, 407-416. [CrossRef]

7. Stojiljkovic, M.M.; Ignjatovic, M.G.; Vuckovic, G.D. Greenhouse Gases Emission Assessment in Residential Sector through Buildings Simulations and Operation Optimization. Energy 2015, 92, 420-434. [CrossRef]

8. Xu, X.; Feng, G.; Chi, D.; Liu, M.; Dou, B. Optimization of Performance Parameter Design and Energy Use Prediction for Nearly Zero Energy Buildings. Energies 2018, 11, 3252. [CrossRef]

9. Kristjansdottir, T.F.; Good, C.S.; Inman, M.R.; Schlanbusch, R.D.; Andresen, I. Embodied Greenhouse Gas Emissions from PV Systems in Norwegian Residential Zero Emission Pilot Buildings. Sol. Energy 2016, 133, 155-171. [CrossRef]

10. Rey-Hernández, J.M.; Velasco-Gómez, E.; San José-Alonso, J.F.; Tejero-González, A.; González-González, S.L.; Rey-Martínez, F.J. Monitoring Data Study of the Performance of Renewable Energy Systems in a Near Zero Energy Building in Spain: A Case Study. Energies 2018, 11, 2979. [CrossRef]

11. Kim, S.H.; Lee, H.J.; Kim, H.J.; Jang, D.H.; Kim, H.-J.; Hur, J.; Cho, Y.-S.; Hur, K. Improvement in Policy and Proactive Interconnection Procedure for Renewable Energy Expansion in South Korea. Renew. Sustain. Energy Rev. 2018, 98, 150-162. [CrossRef]

12. Kampf, J.H.; Robinson, D. A hybrid CMA-ES and HDE Optimisation Algorithm with Application to Solar Energy Potential. Appl. Soft Comput. 2009, 9, 738-745. [CrossRef]

13. Vidal-Amaro, J.J.; Ostergaard, P.A.; Sheinbaum-Pardo, C. Optimal Energy Mix for Transitioning from Fossil Fuels to Renewable Energy Sources-The Case of the Mexican Electricity System. Appl. Energy 2015, 150, 80-96. [CrossRef]

14. European Commission. Towards Nearly Zero-energy Buildings; Definition of Common Principles under the EPBD; ECOFYS Germany GmbH: Köln, Germany, 2013; p. 18.

15. EPA. Energy and Environment Guide to Action; EPA: Washington, DC, USA, 2015; pp. ES-1-ES-2.

16. Lu, Y.; Zhang, X.P.; Huang, Z.; Lu, J.; Wang, D. Impact of Introducing Penalty-cost on Optimal Design of Renewable Energy Systems for Net Zero Energy Buildings. Appl. Energy 2019, 235, 106-116. [CrossRef]

17. Hassoun, A.; Dincer, I. Development of Power System Designs for a Net Zero Energy House. Energy Build. 2014, 73, 120-129. [CrossRef]

18. Richardson, D.B.; Harvey, L.D.D. Optimizing Renewable Energy, Demand Response and Energy Storage to Replace Conventional Fuels in Ontario, Canada. Energy 2015, 93, 1447-1455. [CrossRef]

19. Connolly, D.; Lund, H.; Mathiesen, B.; Leahy, M. The First Step Towards a 100\% Renewable Energy-system for Ireland. Appl. Energy 2011, 88, 502-507. [CrossRef]

20. Hart, E.; Jacobson, M. A Monte Carlo Approach to Generator Portfolios Planning and Carbon Emissions Assessment of Systems with Large Penetrations of Variable Renewables. Renew. Energy 2011, 36, 2278-2286. [CrossRef] 
21. Budischak, C.; Sewell, D.; Thomson, H.; Mach, L.; Veron, D.; Kempton, W. Cost-minimized Combinations of Wind Power, Solar Power and Electrochemical Storage, Powering the Grid up to $99.9 \%$ of the Time. J. Power Sources 2013, 225, 60-74. [CrossRef]

22. Jo, J.H.; Aldeman, M.; Lee, H.S.; Ahn, Y.H. Parametric Analysis for Cost-optimal Renewable Energy Integration into Residential Buildings: Techno-economic Model. Renew. Energy 2018, 125, 907-914. [CrossRef]

23. Ferrara, M.; Monetti, V.; Fabrizio, E. Cost-Optimal Analysis for Nearly Zero Energy Buildings Design and Optimization: A Critical Review. Energies 2018, 11, 1478. [CrossRef]

24. Zubair, M.; Bilal Awan, A.; Al-Ahmadi, A.; Abo-Khalil, A.G. NPC Based Design Optimization for a Net Zero Office Building in Hot Climates with PV Panels as Shading Device. Energies 2018, 11, 1391. [CrossRef]

25. Rubio, R.L.; Trejo-Perea, M.; Vargas-Vazquez, D.; Rios-Moreno, G.J. Optimal Sizing of Renewable Hybrids Energy Systems: A Review of Methodologies. Sol. Energy 2012, 86, 1077-1088. [CrossRef]

26. Celik, A.N. Techno-economic Analysis of Autonomous PV-wind Hybrid Systems Using Different Sizing Methods. Energy Convers. Manag. 2003, 44, 1951-1968. [CrossRef]

27. Devezas, T.; LePoire, D.; Matias, J.C.O.; Silva, A.M.P. Energy Scenarios: Toward a New Energy Paradigm. Futures 2008, 40, 1-16. [CrossRef]

28. Kaundinya, D.P.; Balachandra, P.; Ravindranath, N.H. Grid-connected versus Stand-alone Energy Systems for Decentralized Power-A Review of Literature. Renew. Sustain. Energy Rev. 2009, 13, 2041-2050. [CrossRef]

29. Wang, W.; Zmeureanu, R.; Rivard, H. Applying Multi-objective Genetic Algorithms in Green Building Design Optimization. Build. Environ. 2005, 40, 1512-1525. [CrossRef]

30. Wang, W.; Zmeureanu, R.; Rivard, H. Floor Shape Optimization for Green Building Design. Adv. Eng. Inform. 2006, 20, 363-378. [CrossRef]

31. Tozzi, P., Jr.; Jo, J.H. A Comparative Analysis of Renewable Energy Simulation Tools: Performance Simulation Model vs. System Optimization. Renew. Sustain. Energy Rev. 2017, 80, 390-398. [CrossRef]

32. Moya, D.; Paredes, J.; Kaparaju, P. Technical, Financial, Economic and Environmental Pre-feasibility Study of Geothermal Power Plants by RETScreen-Ecuador's Case Study. Renew. Sustain. Energy Rev. 2018, 92, 628-637. [CrossRef]

33. Khalid, A.; Junaidi, H. Study of Economic Viability of Photovoltaic Electric Power for Quetta-Pakistan. Renew. Energy 2013, 50, 253-258. [CrossRef]

34. Mirzahosseini, A.H.; Taheri, T. Environmental, Technical and Financial Feasibility Study of Solar Power Plants by RETScreen, According to the Targeting of Energy Subsidies in Iran. Renew. Sustain. Energy Rev. 2012, 16, 2806-2811. [CrossRef]

35. Pan, Y.; Liu, L.; Zhu, T.; Zhang, T.; Zhang, J. Feasibility Analysis on Distributed Energy System of Chongming County based on RETScreen Software. Energy 2017, 130, 298-306. [CrossRef]

36. Salehin, S.; Ferdaous, M.T.; Chowdhury, R.M.; Shithi, S.S.; Rofi, M.S.R.B.; Mohammed, M.A. Assessment of Renewable Energy Systems Combining Techno-economic Optimization with Energy Scenario Analysis. Energy 2016, 112, 729-741. [CrossRef]

37. Himri, Y.; Rehman, S.; Setiawan, A.A.; Himri, S. Wind Energy for Rural Areas of Algeria. Renew. Sustain. Energy Rev. 2012, 16, 2381-2385. [CrossRef]

38. Nordman, E.E. Energy Transitions in Kenya's Tea Sector: A Wind Energy Assessment. Renew. Energy 2014, 68, 505-514. [CrossRef]

39. Kosnik, L. The Potential for Small Scale Hydropower Development in the US. Energy Policy 2010, 38, 5512-5519. [CrossRef]

40. Sandt, C.J.; Doyle, M.W. The Hydrologic and Economic Feasibility of Micro Hydropower Upfitting and Integration of Existing Low-head Dams in the United States. Energy Policy 2013, 63, 261-271. [CrossRef]

41. Wijeratne, W.M.P.U.; Yang, R.J.; Too, E.; Wakefield, R. Design and Development of Distributed Solar PV Systems: Do the Current Tools Work? Sustain. Cities Soc. 2019, 45, 553-578. [CrossRef]

42. Zandi, M.; Bahrami, M.; Eslami, S.; Gavagsaz-Ghoachani, R.; Payman, A.; Phattanasak, M.; Nahid-Mobarakeh, B.; Pierfederici, S. Evaluation and Comparison of Economic Policies to Increase Distributed Generation Capacity in the Iranian Household Consumption Sector Using Photovoltaic Systems and RETScreen Software. Renew. Energy 2017, 107, 215-222. [CrossRef]

43. Li, C.; Zhou, D.; Zheng, Y. Techno-economic Comparative Study of Grid-connected PV Power Systems in Five Climate Zones, China. Energy 2018, 165, 1352-1369. [CrossRef] 
44. Malico, I.; Carrajola, J.; Gomes, P.; Lima, J.C. Biomass Residues for Energy Production and Habitat Preservation. Case Study in a Montado Area in Southwestern Europe. J. Clean. Prod. 2016, 112, 3676-3683. [CrossRef]

45. Mallaki, M.; Fatehi, R. Design of a Biomass Power Plant for Burning Date Palm Waste to Cogenerate Electricity and Distilled Water. Renew. Energy 2014, 63, 286-291. [CrossRef]

46. Yilmaz, I.H. Residential Use of Solar Water Heating in Turkey: A Novel Thermo-economic Optimization for Energy Savings, Cost Benefit and Ecology. J. Clean. Prod. 2018, 204, 511-524. [CrossRef]

47. Stevanović, S.; Pucar, M. Financial Measures Serbia Should Offer for Solar Water Heating Systems. Energy Build. 2012, 54, 519-526. [CrossRef]

48. Paudel, A.M.; Sarper, H. Economic Analysis of a Grid-connected Commercial Photovoltaic System at Colorado State University-Pueblo. Energy 2013, 52, 289-296. [CrossRef]

49. Chamorro, C.R.; Mondéjar, M.E.; Ramos, R.; Segovia, J.J.; Martín, M.C.; Villamañán, M.A. World Geothermal Power Production Status: Energy, Environmental and Economic Study of High Enthalpy Technologies. Energy 2012, 42, 10-18. [CrossRef]

50. Born, F.J.; Clarke, J.A.; Johnstone, C.M. Development and Demonstration of a Renewable Energy Based Energy Demand/Supply Decision Support Tool for the Building Design Profession. In Proceedings of the 7th International IBPSA Conference, Rio de Janeiro, Brazil, 13-15 August 2001; pp. 245-250.

51. Born, F.; Clarke, J.; Johnstone, C.; Kelly, N.; Burt, G.; Dysko, A.; McDonald, J.; Hunter, I.B.B. On the Integration of Renewable Energy Systems within the Built Environment. Build. Serv. Eng. Res. Technol. 2001, 22, 3-13. [CrossRef]

52. HOMER Pro. Available online: https://www.homerenergy.com/products/pro/index.html (accessed on 20 December 2018).

53. Zhang, S.; Huang, P.; Sun, Y. A Multi-criterion Renewable Energy System Design Optimization for Net Zero Energy Buildings under Uncertainties. Energy 2016, 94, 654-665. [CrossRef]

54. Lu, Y.; Wang, S.; Zhao, Y.; Yan, C. Renewable Energy System Optimization of Low / zero Energy Buildings Using Single-objective and Multi-objective Optimization Methods. Energy Build. 2015, 89, 61-75. [CrossRef]

55. Sharafi, M.; Tarek, Y.E.; Bibeau, E.L. Optimal Design of Hybrid Renewable Energy Systems in Buildings with Low to High Renewable Energy Ratio. Renew. Energy 2015, 83, 1026-1042. [CrossRef]

56. Kim, J.; Kim, E.-J. Simplified Method of Optimal Sizing of a Renewable Energy Hybrid System for Schools. Sustainability 2016, 8, 1134. [CrossRef]

57. Ministry of Trade, Industry and Energy. Mandatory Installation of Renewable Energy systems for New/ Remodeling/Renovation Public Buildings; Ministry of Trade, Industry and Energy: Sejong City, Korea, 2018; pp. 5-6.

58. Monaaf, D.A.A.; Jayasinghe, S.D.G.; Enshaei, H. A Review on Recent Size Optimization Methodologies for Standalone Solar and Wind Hybrid Renewable Energy System. Energy Convers. Manag. 2017, 143, 252-274.

59. 50\% Renewable Energy Would Put Australia in Line with Leading Nations. Available online: http: / / theconversation.com/50-renewable-energy-would-put-australia-in-line-with-leading-nations-45152 (accessed on 5 January 2019).

60. Inside Arizona's Latest Clash over Renewable Energy Targets. Available online: https://www. greentechmedia.com/articles/read/arizona-clash-over-renewable-energy-targets\#gs.B3fMX47H (accessed on 5 January 2019).

61. Environment Minnesota Endorese Sen. Tina Smith and Dean Phillips for Congress. Available online: https:/ / environmentamerica.org/page/ame/environment-minnesota-endorses-sen-tina-smithand-dean-phillips-congress (accessed on 5 January 2019).

62. Jamaica Announces Goal for 50\% Renewable Energy by 2030. Available online: http:/ / newenergyevents. com/jamaica-announces-goal-for-50-renewable-energy-by-2030/ (accessed on 13 January 2019).

(C) 2019 by the authors. Licensee MDPI, Basel, Switzerland. This article is an open access article distributed under the terms and conditions of the Creative Commons Attribution (CC BY) license (http://creativecommons.org/licenses/by/4.0/). 